\title{
Trends and disparities in the use of cholinesterase inhibitors to treat Alzheimer's disease dispensed by the Brazilian public health system - 2008 to 2014: a nation-wide analysis
}

Tendência e desigualdade no uso de anticolinesterásicos para tratamento de doença de Alzheimer dispensados pelo sistema de saúde público do Brasil - 2008 e 2014: uma análise nacional

Flávia Silva de Moraes', Mariana Lima Cerqueira de Souza', Giancarlo Lucchetti ${ }^{1}$, Alessandra Lamas

Granero Lucchetti'

\begin{abstract}
In light of the high cost of dementia treatment, there is legislation authorizing free distribution of cholinesterase inhibitors to those suffering from Alzheimer's disease in Brazil. However, the existence of this free distribution does not guarantee adequate distribution. Objectives: The present study aimed to investigate the trends of prescriptions and the coverage of Alzheimer's disease treatment using cholinesterase inhibitors from public pharmacies dispensing high-cost drugs in Brazil. Methods: This was a retrospective study that collected data from the Brazilian public Unified Health System. All cholinesterase inhibitors distributed at no cost to Brazilians during the year 2014, as well as the estimated number and percentages of patients who used these medications, were evaluated and compared to data from the year 2008. Results: Our estimates indicated that $9.7 \%$ of the population having dementia syndromes used cholinesterase inhibitors, as well as $16.1 \%$ of those with Alzheimer's disease in Brazil. A clear disparity was noted between the use and distribution of cholinesterase inhibitors, depending on the region in which they were found. Over time, an increase in the distribution of cholinesterase inhibitors has been noted. In 2008, that use was $12.0 \%$ whereas, in 2014, it was $16.1 \%$, an increase of $34 \%$ in six years. Conclusion: It was estimated that $16.1 \%$ of patients with Alzheimer's disease in Brazil use cholinesterase inhibitors. These values have increased and, in spite of not being satisfactory, they indicate a potential for improvement. However, there is still a significant disparity among the regions.
\end{abstract}

Keywords: cholinesterase inhibitors; public health; dementia; Alzheimer's disease

RESUMO

Devido ao custo alto de tratamento, existe uma legislação autorizando a distribuição sem custo de anticolinesterásicos para pacientes com doença de Alzheimer no Brasil. Entretanto, a existência dessa distribuição gratuita nem sempre garante uma distribuição adequada. Objetivos: 0 presente estudo objetiva investigar a distribuição e desigualdades no uso de anticolinesterásicos (AChE) dispensados pelo Sistema de Saúde Público do Brasil. Métodos: Estudo retrospectivo que coletou dados do Sistema Único de Saúde brasileiro. Foram avaliados todos os anticolinesterásicos distribuídos sem custo no Brasil durante o ano de 2014, assim como o número estimado e a porcentagem de pacientes que usavam essa medicação. Esses dados foram comparados com o ano de 2008. Resultados: Estima-se que 9,7\% da população que possui síndromes demenciais usa anticolinesterásicos, assim como 16,1\% dos pacientes com doença de Alzheimer. Uma clara desigualdade entre o uso e a distribuição dos anticolinesterásicos foi encontrada, variando de acordo com a região. Houve um aumento na distribuição de anticolinesterásicos ao longo do tempo. Em 2008, o uso era de 12\% e, em 2014, foi de 16,1\%, resultando em um aumento de 34\% em 6 anos. Conclusão: Estima-se que 16,1\% dos pacientes com doença de Alzheimer no Brasil usam anticolinesterásicos. Esses valores tiveram um aumento e, embora ainda não sejam satisfatórios, eles indicam um potencial de melhora. Entretanto, ainda foi evidenciada uma significante desigualdade entre as regiões.

Palavras-chave: Inibidores da colinesterase; saúde pública; demência; Doença de Alzheimer

'Unversidade Federal de Juiz de Fora, Faculdade de Medicina, Juiz de Fora MG, Brasil.

Correspondence: Giancarlo Lucchetti; Faculdade de Medicina da UFJF; Av. Eugênio do Nascimento s/n; 36038-330 Juiz de Fora MG, Brasil; E-mail: g.lucchetti@yahoo.com.br

Conflict of interest: There is no conflict of interest to declare.

Received 08 December 2017; Received in final form 08 March 2018; Accepted 10 April 2018. 
The aging population is a global process that is altering the characterization of modern society, and Brazil is considered one of the developing countries with the highest rates of demographic aging. This rapid Brazilian demographic transition brings with it new demands on public health services, which need to direct measures and resources to the treatment of older persons. Among health problems occurring more frequently in this phase of life, neurodegenerative diseases, including dementia syndromes, have a high prevalence, affecting approximately $8.5 \%$ of older people in Latin America².

Alzheimer's disease $(\mathrm{AD})$ is the main cause of irreversible dementia in older Brazilians ${ }^{3}$, and is characterized by neuron loss that leads to cognitive (memory, orientation, language, and attention) deficits as well as functional, social, and occupational impairments. In spite of AD's physiopathology not being totally known, studies indicate that alterations in the concentration of acetylcholine are responsible for part of the disease's symptoms ${ }^{4}$. Based on the possible cholinergic deficit and aiming to increase that substance's synaptic availability, cholinesterase inhibitors are the principal drugs currently used for the specific treatment of this disease. They also act by inhibiting catalytic enzymes such as, acetyl- and butyrylcholinesterase. This therapy is aimed at improving patients' quality of life and keeping them independent longer in their activities of daily living ${ }^{5}$.

The cholinesterase inhibitors approved for use in Brazil are rivastigmine, donepezil and galantamine. The estimated annual cost of treatment for persons with $\mathrm{AD}$ varies from US\$868 in very low income regions to US\$32,865 in high income regions per person ${ }^{6}$. In light of this treatment's high cost, there is legislation authorizing free distribution of cholinesterase inhibitors to those suffering from mild to moderate $\mathrm{AD}$ in Brazil, according to the authority established in Article 5 of the Decree GM/MS no. 1230, from October 14, 1999, which includes the list of medications for $\mathrm{AD}$ in the Ambulatory Information System of Brazil's Unified Health System for medications that should be distributed.

The distribution of medication for treating $\mathrm{AD}$ is based on the evidence-based Brazilian public guidelines ${ }^{7}$, used by Brazil's Ministry of Health since 2002. In addition to the pharmaceuticals already cited, there are other therapeutic possibilities that include transdermal rivastigmine and orallyadministered memantine ${ }^{8}$. They, however, were not freely distributed until the end of 2017. The absence of these two medications in the Brazilian public guidelines had resulted in judicial demands that they be distributed, increasing costs for the Unified Health System (SUS) in its diverse governmental entities.

In spite of being well structured, the existence of the Brazilian public guidelines does not guarantee the measure's total effectiveness. Difficulties are encountered in adequate distribution, like accessibility and availability proportional to the number of cases in each municipality9. Prioritizing adequate distribution of drugs indicated for treatment of $\mathrm{AD}$, in light of its importance to both patients and the national public health system, makes it necessary to evaluate whether or not there is a convenient association between the estimated number of those suffering from the disease and the distribution of high-cost medications throughout the country's federative units.

This study's objective was to investigate the trends of prescription (in 2008 and 2014) and the coverage of AD treatment using cholinesterase inhibitors from pharmacies dispensing high-cost drugs in Brazil, evaluating the types of medication most often used and the regions that dispense the most medications. We also compared the different regions in relation to coverage of treatment for dementia in general and for $\mathrm{AD}$.

\section{METHODS}

This was a retrospective study collecting data from the Brazilian public Unified Health System. This data collection did not need approval by an ethics committee as it dealt with governmental databanks for public access and use, according to Brazil's National Council of Health Resolution CNS 466/12.

The study was conducted for the year 2015, extracting data on the use of cholinesterase inhibitors contained in the Information Technology Department of the Unified Health System's (DATASUS's) “Health Information (TABNET)”. In order to extract the data, DATASUS was accessed using the link http://www2.datasus.gov.br/DATASUS/index.php?area=02. In "Health Services", "Ambulatory Production" was chosen and in "Procedure", categories related to cholinesterase inhibitors were selected ( for example: 0601220030: rivastigmine (N) 1.5 MG - BY CAPSULE). Once the cholinesterase inhibitor was selected, the quantity approved for each municipality in each state was consulted. This data was exported to Excel tables for later compilation.

To extract the number of older people in Brazil and its states, the Brazilian Institute of Geography and Statistics site was used, following the link http://www.ibge.gov.br/apps/ snig/v1/?loc=0,P12,P27\&cat=-1,-2,8,128\&ind $=4711$ and also exported to an Excel table.

In order to facilitate the comparison of data with a previous study using the same method of collection, we opted to use a prevalence of dementia of $7.1 \%$ in Brazil and, of the patients with dementia, it was estimated that $60 \%$ had $\mathrm{AD}^{10}$.

Thus, 20,589,903 older people were counted by the Brazilian Institute of Geography and Statistics for the year 2010 (the year in which the demographic census was conducted). We then estimated that 1,461,812 were suffering from dementia and 877,087 from AD. The number of patients who used cholinesterase inhibitors was calculated by dividing the number of pills dispensed by one year (365 days). In other words, we considered that each patient would 
use one cholinesterase inhibitor pill per day, which is the correct dosage in the case of galantamine and donepezil. That, however, overestimates the use of rivastigmine, which calls for a maximum dosage of two per day. We opted not to include rivastigmine oral solution $2 \mathrm{mg} / \mathrm{ml}$ in the study as it is the only formula using drops, and it was observed that its values were not statistically significant (corresponding to less than $0.2 \%$ of medications dispensed) during our initial analysis. At that time, transdermal rivastigmine and memantine were not provided free of cost by the Brazilian public health system.

Once we had determined the number of patients who used cholinesterase inhibitors, we estimated the percentage of patients with dementia and with $\mathrm{AD}$ in both Brazil, and each state, being treated for their condition (coverage of the use of cholinesterase inhibitors).

Finally, the goal of furnishing cholinesterase inhibitor drugs to at least $50 \%$ of Alzheimer's patients was used. This goal was based on a previous study ${ }^{10}$ and was guided by the premise that half of the patients had advanced stage AD, intolerance to cholinesterase inhibitors and/or criteria for exclusion from using the medication, as established in Decree 843, of the Brazilian Clinical Protocol and Therapeutics Directives for Alzheimer's Disease.

\section{RESULTS}

In the year 2014, a total of 39,431,562 doses of cholinesterase inhibitors were distributed by pharmacies dispensing high-cost drugs in Brazil. Of these, $47.2 \%$ were rivastigmine, $36.3 \%$ were donepezil, and $16.5 \%$ galantamine. The most frequently dispensed was donepezil $10 \mathrm{mg}$ (22.7\%), followed by rivastigmine $3 \mathrm{mg}$ (15\%) and rivastigmine $6 \mathrm{mg}$ (14.3\%). The Southeast region dispensed the higher number of drugs (69.3\%), followed by the South $(13.5 \%)$ and the Northeast (12.5\%). São Paulo was the state with the greatest rate of distribution (52.9\%), followed by Minas Gerais (8.7\%), and Paraná (8.4\%). The description of the most-frequently used dosages of cholinesterase inhibitor can be found in Table 1.

Table 2 shows the estimated percentage of patients using cholinesterase inhibitors. Considering the use of one cholinesterase inhibitor pill per day, we found that $9.7 \%$ of the population with dementia syndromes, and $16.1 \%$ of those with $\mathrm{AD}$, used that medication.

In separating out the states, we took note of the clear disparity among both the use and distribution of cholinesterase inhibitors, depending on the region in which they were found. Considering the use for dementia in general, the region with the highest estimated usage of cholinesterase inhibitors was the Southeast $(11.1 \%)$, followed by the South (6.2\%), the Central-West (4.5\%), the Northeast (3.5\%), and the North (1.6\%). As for the states, Espírito Santo had the highest percentage of use (18.5\%), followed by São
Paulo (16.9\%), and Paraná (10.9\%). Considering use for $\mathrm{AD}$, the region with the highest estimated use of cholinesterase inhibitors was the Southeast (18.4\%), followed by the South (10.4\%), the Central-West (7.5\%), Northeast (5.8\%), and the North (2.6\%). Of the states, Espírito Santo had the highest percentage of use (30.9\%), followed by São Paulo (28.1\%) and Paraná (18.2\%).

Table 3 shows the comparison between the data extracted for 2008, published by Moraes et al. ${ }^{10}$ and the data extracted for 2014, published in this study. An increase in the use of cholinesterase inhibitors dispensed in pharmacies distributing high-cost drugs was noted. In 2008, that usage was $12.0 \%$, while in 2014 it was $16.1 \%$, an increase of $34 \%$ in six years. In spite of some states having had an important increase (São Paulo, Espírito Santo, Mato Grosso do Sul, and Paraná), other states showed a decrease in medications distributed (Minas Gerais, Piauí, Rio Grande do Norte, and Sergipe).

If we consider the Brazilian government's goal of $50 \%$ of $\mathrm{AD}$ patients being treated, we note that there was a growth from $24 \%$ to $32.2 \%$ of the goal, with some states such as Espírito Santo (61.8\%) and São Paulo (56.2\%) being closer to the goal than others.

\section{DISCUSSION}

This study has shown that, despite still being far below the goal of $50 \%$, there has been an increase in dispensing cholinesterase inhibitor drugs in Brazil in recent years. In spite of this increase, there still is significant heterogeneity among the country's regions, with some states being near the goal and others still very distant.

In the year 2014, Brazil reached a $16.1 \%$ distribution of cholinesterase inhibitor drugs furnished by the Brazilian public Unified Health System, an increase when compared to the numbers for 2008 , in which distribution was $12 \%$. In a multicenter European study, the authors found that the prevalence of cholinesterase inhibitor use for patients with dementia was $10.3 \%$, with a variation from $3.0 \%$ for Holland to $20.3 \%$ for France ${ }^{11}$. Despite these results being similar to those found in our study, where we found a prevalence of 9.7\% for all of Brazil (varying from 0.3\% in Amapá to 16.9\% in São Paulo), the European study was conducted in 2004, which leads to the expectation that these numbers may have been much higher in 2014, when our study was conducted. The under-treatment rates observed by this and also by international studies may be directly related to the under-diagnosis of this condition worldwide, showing the need for global awareness and training for the identification of $\mathrm{AD}$ and other dementia syndromes.

Another fact to be highlighted is the nearly $35 \%$ growth in the use of cholinesterase inhibitors in Brazil in six years (2008 to 2014). This pattern of increased treatment is also 


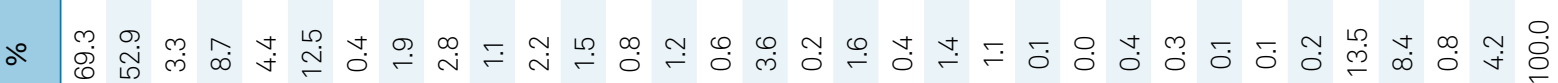

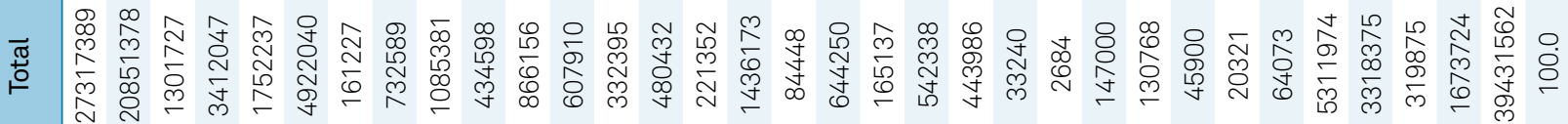

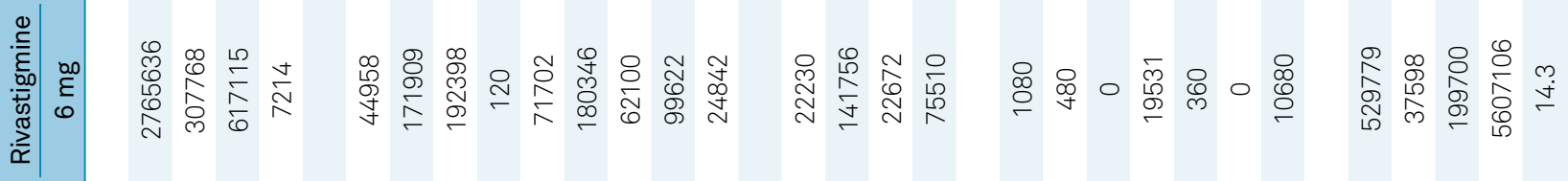

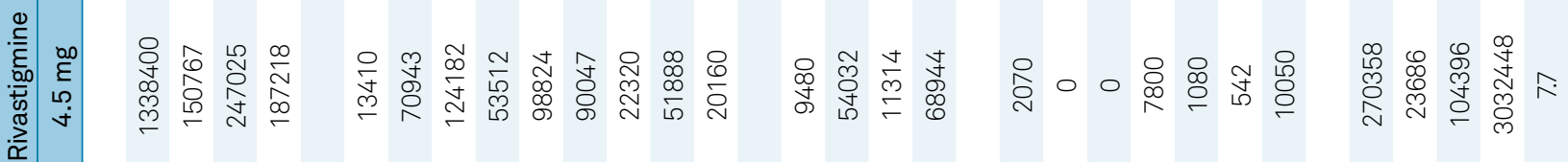

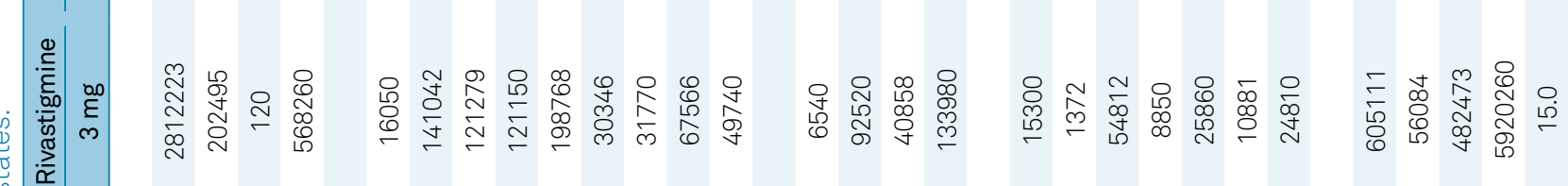

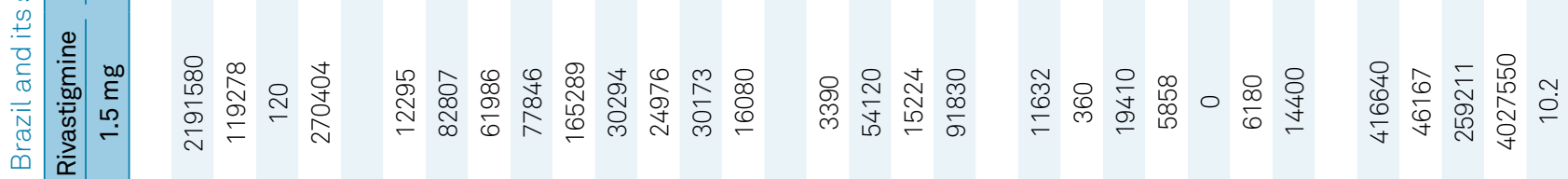

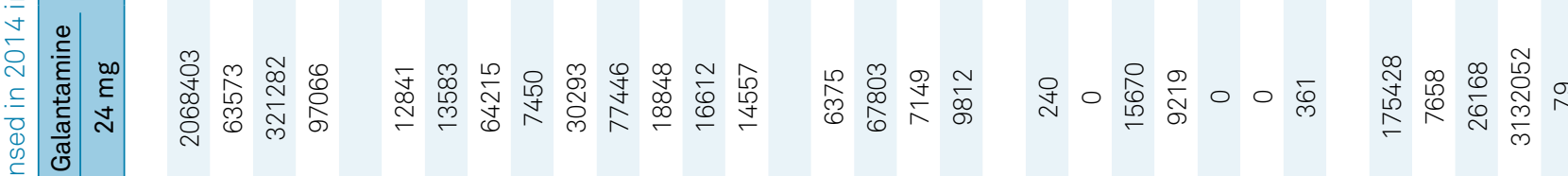

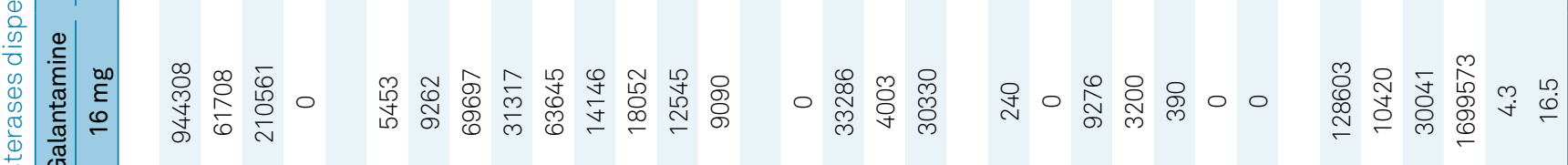
$\begin{array}{llll} & \\ 0 & & \\ 0\end{array}$

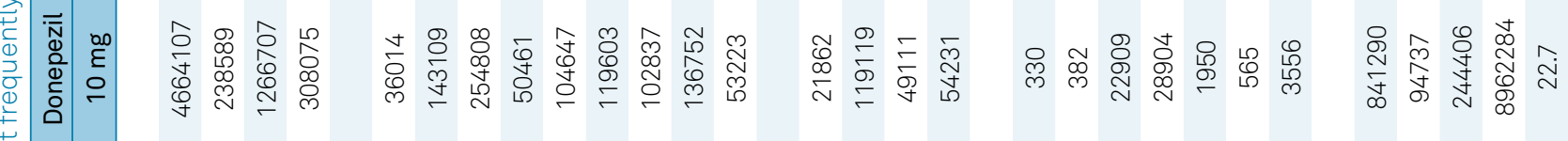

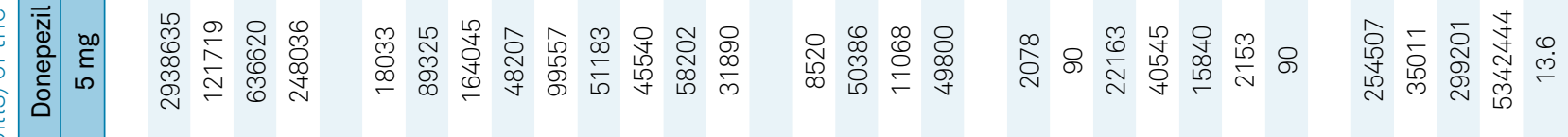


Table 2. The use of anticholinesterases from pharmacies dispensing high-cost drugs in the year 2014 in Brazil and its Regions/States.

\begin{tabular}{|c|c|c|c|c|c|c|}
\hline Region/State & $\begin{array}{c}\text { Total of } \\
\text { pills }\end{array}$ & $\begin{array}{l}\text { Total estimate of patients } \\
\text { using cholinesterase } \\
\text { inhibitors }\end{array}$ & $\begin{array}{c}\text { Total estimate } \\
\text { of patients } \\
\text { with dementia }\end{array}$ & $\begin{array}{l}\% \text { treated dementia } \\
\text { with cholinesterase } \\
\text { inhibitors }\end{array}$ & $\begin{array}{l}\text { Estimate of } \\
\text { patients with } \\
\text { Alzheimer }\end{array}$ & $\begin{array}{c}\% \text { treated Alzheimer } \\
\text { with cholinesterase } \\
\text { inhibitors }\end{array}$ \\
\hline Southeast & 27317389 & 74842 & 676437 & $11.1 \%$ & 405862 & 18.4 \\
\hline São Paulo & 20851378 & 57127 & 338799 & $16.9 \%$ & 203280 & 28.1 \\
\hline Rio de Janeiro & 1301727 & 3566 & 147645 & $2.4 \%$ & 88587 & 4.0 \\
\hline Minas Gerais & 3412047 & 9348 & 164087 & $5.7 \%$ & 98452 & 9.5 \\
\hline Espírito Santo & 1752237 & 4801 & 25905 & $18.5 \%$ & 15543 & 30.9 \\
\hline Northeast & 4922040 & 13485 & 387101 & $3.5 \%$ & 232261 & 5.8 \\
\hline Alagoas & 161227 & 442 & 19608 & $2.3 \%$ & 11765 & 3.8 \\
\hline Bahia & 732589 & 2007 & 102951 & $1.9 \%$ & 61770 & 3.2 \\
\hline Ceará & 1085381 & 2974 & 64554 & $4.6 \%$ & 38733 & 7.7 \\
\hline Maranhão & 434598 & 1191 & 40304 & $3.0 \%$ & 24182 & 4.9 \\
\hline Paraíba & 866156 & 2373 & 32028 & $7.4 \%$ & 19217 & 12.3 \\
\hline Pernambuco & 607910 & 1666 & 66510 & $2.5 \%$ & 39906 & 4.2 \\
\hline Piauí & 332395 & 911 & 23556 & $3.9 \%$ & 14133 & 6.4 \\
\hline Rio Grande do Norte & 480432 & 1316 & 24384 & $5.4 \%$ & 14631 & 9.0 \\
\hline Sergipe & 221352 & 606 & 13206 & $4.6 \%$ & 7924 & 7.7 \\
\hline Central West & 1436173 & 3935 & 87932 & $4.5 \%$ & 52759 & 7.5 \\
\hline Distrito Federal & 84448 & 231 & 14059 & $1.6 \%$ & 8435 & 2.7 \\
\hline Goiás & 644250 & 1765 & 39792 & $4.4 \%$ & 23875 & 7.4 \\
\hline Mato Grosso & 165137 & 452 & 17070 & $2.7 \%$ & 10242 & 4.4 \\
\hline Mato Grosso do Sul & 542338 & 1486 & 17011 & $8.7 \%$ & 10207 & 14.6 \\
\hline North & 443986 & 1216 & 76770 & $1.6 \%$ & 46062 & 2.6 \\
\hline Acre & 33240 & 91 & 3323 & $2.7 \%$ & 1994 & 4.6 \\
\hline Amapá & 2684 & 7 & 2466 & $0.3 \%$ & 1480 & 0.5 \\
\hline Amazonas & 147000 & 403 & 14922 & $2.7 \%$ & 8953 & 4.5 \\
\hline Pará & 130768 & 358 & 37947 & $0.9 \%$ & 22768 & 1.6 \\
\hline Rondônia & 45900 & 126 & 8006 & $1.6 \%$ & 4804 & 2.6 \\
\hline Roraima & 20321 & 56 & 1759 & $3.2 \%$ & 1056 & 5.3 \\
\hline Tocantins & 64073 & 176 & 8346 & $2.1 \%$ & 5007 & 3.5 \\
\hline South & 5311974 & 14553 & 233573 & $6.2 \%$ & 140144 & 10.4 \\
\hline Paraná & 3318375 & 9091 & 83223 & $10.9 \%$ & 49934 & 18.2 \\
\hline Rio Grande do Sul & 319875 & 876 & 103765 & $0.8 \%$ & 62259 & 1.4 \\
\hline Santa Catarina & 1673724 & 4586 & 46586 & $9.8 \%$ & 27951 & 16.4 \\
\hline Total & 39431562 & 141221 & 1461812 & $9.7 \%$ & 877087 & 16.1 \\
\hline
\end{tabular}

confirmed by other studies. In Germany, for example, the standardized prevalence of cholinesterase inhibitors for people aged 65 or older, doubled in a period of eight years $(2000$ to 2007$)^{12}$ and in Italy, there was an increase of $40 \%$ in the prescription of these medications from 2002 to $2007^{13}$. However, a recent study carried out in France showed an increase in prescription rates between 2006 and 2010 and a decrease in prescription rates from 2011 to $2014^{14}$.

In regard to the types of cholinesterase inhibitors prescribed, we found that in Brazil, the most frequently-used drug was rivastigmine, at more than $47 \%$ of prescriptions. On the other hand, donepezil was the most common drug (greater than $50 \%)^{11}$ in European countries like Belgium, France, Germany, Italy, the Netherlands, Poland, Portugal, Spain, and the United Kingdom in 2004, a result similar to that of the United States $(66.3 \%)^{15}$. The decision for the use of cholinesterase inhibitors, independent of $\mathrm{AD}$ severity, should be based on each professional's experience ${ }^{16}$ and studies have still failed to demonstrate greater effectiveness of one drug over the other ${ }^{17}$.

In spite of the notable increase in levels of distribution, the rates of treatment for dementia and $\mathrm{AD}$ are still very low. We considered possible factors that have prevented the Brazilian government's goal being reached. First, concerning the differences between the treatment rates of dementia and $\mathrm{AD}$, we highlight that cholinesterase inhibitors, available free of cost in Brazil, are only provided to patients who fulfill the clinical diagnostic criteria established by the Brazilian guidelines for $\mathrm{AD}$ and not to patients with other types of dementia ${ }^{18}$. This may have influenced the differences found in the present study between the treatment for dementia syndromes (9.7\%) and for $\mathrm{AD}(16.1 \%)$.

Second, not infrequently, the prescription of other drugs for monotherapeutic and/or complementary treatment for $\mathrm{AD}$, as exemplified by Ginkgo Biloba has been observed. In vitro studies have shown three biological benefits of this 
Table 3. Comparison between the use of anticholinesterase drugs in the year 2008 and in the year 2014 in relation to the Brazilian government's goals for treating AD patients (\%).

\begin{tabular}{|c|c|c|c|c|}
\hline Region/State & $2008 *$ & $\begin{array}{c}\text { Goal in relation to the AD } \\
\text { program }(50 \%)\end{array}$ & 2014 & $\begin{array}{l}\text { Goal in relation to the } A D \\
\text { program }(50 \%)\end{array}$ \\
\hline Southeast & 16.9 & 33.8 & 18.4 & 36.8 \\
\hline São Paulo & 22.3 & 44.6 & 28.1 & 56.2 \\
\hline Rio de Janeiro & 2.5 & 5.0 & 4.0 & 8.0 \\
\hline Minas Gerais & 18.4 & 36.8 & 9.5 & 19.0 \\
\hline Espírito Santo & 22.1 & 44.2 & 30.9 & 61.8 \\
\hline Northeast & 8.2 & 16.4 & 5.8 & 11.6 \\
\hline Alagoas & 7.3 & 14.6 & 3.8 & 7.6 \\
\hline Bahia & 4.1 & 8.2 & 3.2 & 6.4 \\
\hline Ceará & 14.4 & 28.8 & 7.7 & 15.4 \\
\hline Maranhão & 4.7 & 9.4 & 4.9 & 9.8 \\
\hline Paraíba & 11.5 & 23.0 & 12.3 & 24.6 \\
\hline Pernambuco & 4.0 & 8.0 & 4.2 & 8.4 \\
\hline Piauí & 14.4 & 28.8 & 6.4 & 12.8 \\
\hline Rio Grande do Norte & 16.7 & 33.4 & 9.0 & 18.0 \\
\hline Sergipe & 10.9 & 21.8 & 7.7 & 15.4 \\
\hline Central West & 6.0 & 12.0 & 7.5 & 15.0 \\
\hline Distrito Federal & 3.6 & 7.2 & 2.7 & 5.4 \\
\hline Goiás & 4.1 & 8.2 & 7.4 & 14.8 \\
\hline Mato Grosso & 6.4 & 12.8 & 4.4 & 8.8 \\
\hline Mato Grosso do Sul & 12.1 & 24.2 & 14.6 & 29.2 \\
\hline North & 2.3 & 4.6 & 2.6 & 5.2 \\
\hline Acre & 2.8 & 5.6 & 4.6 & 9.2 \\
\hline Amapá & 1.2 & 2.4 & 0.5 & 1.0 \\
\hline Amazonas & 1.3 & 2.6 & 4.5 & 9.0 \\
\hline Pará & 1.8 & 3.6 & 1.6 & 3.2 \\
\hline Rondônia & 5.1 & 10.2 & 2.6 & 5.2 \\
\hline Roraima & 3.1 & 6.2 & 5.3 & 10.6 \\
\hline Tocantins & 4.1 & 8.2 & 3.5 & 7.0 \\
\hline South & 8.7 & 17.4 & 10.4 & 20.8 \\
\hline Paraná & 13.9 & 27.8 & 18.2 & 36.4 \\
\hline Rio Grande do Sul & 1.6 & 3.2 & 1.4 & 2.8 \\
\hline Santa Catarina & 15.6 & 31.2 & 16.4 & 32.8 \\
\hline Total & 12.0 & 24.0 & 16.1 & 32.2 \\
\hline
\end{tabular}

substance: prevention of neurotoxicity by amyloid beta, the inhibition of apoptotic pathways, and protection from oxidative damage ${ }^{19}$. Nevertheless, previous randomized trials have revealed that long-term use of Ginkgo Biloba extract did not reduce the risk of AD's progression when compared with a placebo ${ }^{20,21}$.

Third, treatment with cholinesterase inhibitors needs periodic reevaluation, every six months, to analyze the drug's effectiveness ${ }^{18}$. If the patient has shown no improvement in, or stagnation of, his or her condition, the medication could be discontinued, as well as if cognition has been severely impaired (very low scores on the MiniMental State Examination) ${ }^{22}$. However, longer periods for reevaluation of the cholinesterase inhibitors use may lead the patient to discontinue the treatment or may prevent an increase in its dosage.

Fourth, cholinesterase inhibitors are not free of adverse effects $^{23}$. Intolerance to cholinesterase inhibitors is a relevant factor for nonadherence to the treatment employed. The most common adverse effects are insomnia, headaches, nausea, vomiting, anorexia, and dyspepsia. Less common are somnolence, dizziness, depression, urinary symptoms, syncope, bradycardia, tremors, and fatigue. Precaution is emphasized for patients with peptic ulcers, a history of convulsions, alterations in cardiac conduction, and asthma ${ }^{23}$.

Fifth, diverse factors may also contribute to under-diagnosis or delay in the diagnosis, which results in the detection of $\mathrm{AD}$ only at already-advanced stages. Commonly, the disease's first symptoms are seen by family members as a "natural" manifestation of aging, resulting in delays in consulting a specialist ${ }^{24}$. There may also be a conflict of differential diagnoses, such as depression and B12 hypovitaminosis, the failure of the professional, and/or the lack of resources for diagnostic investigation of probable $\mathrm{AD}$.

Sixth, the international literature emphasizes the relationship between $\mathrm{AD}$ and high costs ${ }^{25}$, which could lead to less 
medical treatment due to the inability to buy the medication. In Brazil, despite the costs of medications still being high, this is mitigated by free public distribution of medication for all citizens, regardless of their socioeconomic condition ${ }^{26}$.

Seventh, several guidelines have downgraded the evidence status of the cholinesterase inhibitors, indicating their use for moderate to advanced dementia in England and considering their clinical added value as minor in France ${ }^{14}$.

Another important finding of the present study was the clear disparity in the distribution of medications in Brazil, a result that has also been confirmed by other international studies such as one conducted in Australia, which found that geographic isolation and lower socioeconomic conditions were associated with lower rates of prescriptions of cholinesterase inhibitors ${ }^{27}$, and another in the United Kingdom, which found that rates of prescriptions of cholinesterase inhibitors diminished as inequality and financial needs increased ${ }^{28}$.

In the specific case of Brazil, based on analysis by Moraes et al..$^{10}$, and taking into consideration the Program for Supporting Alzheimer's Disease patients' rate of coverage in the year 2008, an increase was noted in the national average of cholinesterase inhibitors distributed by pharmacies dispensing high-cost drugs in 2014, despite some states having a decrease of more than $50 \%$, as in the case of Amapá. It was also observed that this disproportion was maintained among the federative units, facts justified by the socioeconomic inequality that determines access to public health and the minimum quality of infrastructure necessary, as well as the disparity between the number of specialized doctors in each region.

The region with the highest use of cholinesterase inhibitors was the Southeast, followed by the South, the Northeast, the Central West and the North. This is similar to the socioeconomic status of each state considering the gross domestic product, of which the Southeast and the South have highest. This corroborates that the socioeconomic condition is an important determinant for the dispensing of medications. The same results are found if we analyze the number of doctors and specialists. The national rate for specialists/generalists (doctors without specialization) is $1: 41$. While the South has the highest proportion of specialists in relation to generalists at 2:11, the North has the lowest, at 0:94, which can have an impact on the diagnosis and executing the Program for Supporting Alzheimer's Disease patients ${ }^{29}$. We need to point out that Rio Grande do Sul, the Federal District, and Rio de Janeiro stand out in the difference between the percentages of distribution and their per capita income for 2014. That can be justified by the fact that all Brazilian states have autonomy to determine how medication is dispensed. Some states demand that specific protocols be followed, others demand examinations that are not readily available in the Brazilian public Unified Health System (for, example, magnetic resonance imaging of the brain), and certain states only give the medication to patients treated in certain reference centers ${ }^{10}$.
Other factors could also be responsible for the disparities observed in this study. Some states with poorer socioeconomic conditions tend to have fewer medical specialists trained to prescribe cholinesterase inhibitors and this may impact the $\mathrm{AD}$ diagnosis and treatment as reported above. Another problem is that patients who live in smaller cities may travel to other cities in order to obtain the cholinesterase inhibitors ${ }^{9}$. This is a considerable problem in some large states (e.g. North states), in which there are few centers distributing the medications. Some patients may not want to travel several hours to obtain the medication and this could result in under-treatment.

Other possible explanation for this inequality is the administrative processing in supplying cholinesterase inhibitors, since these medications should first be analyzed and approved before being dispensed. A recent study in the State of Minas Gerais (considered a State with high socioeconomic status) showed an average of 39 days for the entire initial administrative process 9 . In other federative states this process could possibly take even longer. Finally, some processes may not be approved for several reasons, such as not fulfilling all inclusion criteria, misdiagnosis, lack of carrying out specific tests (e.g. Mini-Mental State Examination) or incorrect dosage. Therefore, physicians in states with specialized medical centers and universities may be more trained and informed to deal with the administrative processing, which could possibly result in an increased rate of approval of the dispensed drugs.

This study has some limitations that should be taken into consideration. The search for data was done using online government platforms, which can suffer interference because information is manually uploaded and is, therefore, subject to error, making possible an under- or over-notification of information in regard to the distribution of cholinesterase inhibitors by pharmacies dispensing high-cost medications. On the other hand, this data is constantly audited, as it refers to all medications distributed and paid for by the government. Another limitation is the fact that this data does not include commercialization of these medications by the private sector. Even though relatively infrequent in Brazil, this does exist. Finally, the prevalence of dementia and $\mathrm{AD}$ has been estimated in accordance with previous surveys by region. It may, therefore, not correspond to the exact proportion of patients with the disease in each region.

The Brazilian government's goal is to reach $50 \%$ of those suffering from AD. In the year 2014, Brazil reached 16.1\% patients, more than in 2008 and that, despite still being unsatisfactory, indicates growth in Brazil and a potential for improvement in the public program for distributing high-cost medication. Nevertheless, upon taking a more individualized look at the federative units, we recognize significant disparities among some states, principally those in the North that always standout negatively no matter what criteria are used. Analysis of the data shows the need for major directing of public health measures and access to information for regions with lower indices of distribution. 
1. Mendes ACG, Sa DA, Miranda GM, Lyra TM, Tavares RA. [The public healthcare system in the context of Brazil's demographic transition: current and future demands]. Cad Saúde Pública. 2012 May;28(5):955-64. Portuguese. https://doi.org/10.1590/S0102-311X2012000500014

2. Prince M, Bryce R, Albanese E, Wimo A, Ribeiro W, Ferri CP. The global prevalence of dementia: a systematic review and metaanalysis. Alzheimers Dement. 2013 Jan;9(1):63-75.e2. https://doi.org/10.1016/j.jalz.2012.11.007

3. Suemoto CK, Ferretti-Rebustini RE, Rodriguez RD, Leite RE, Soterio L, Brucki SM et al. Neuropathological diagnoses and clinical correlates in older adults in Brazil: A cross-sectional study. PLoS Med. 2017 Mar;14(3):e1002267. https://doi.org/10.1371/journal.pmed.1002267

4. Terry AV Jr, Buccafusco JJ. The cholinergic hypothesis of age and Alzheimer's disease-related cognitive deficits: recent challenges and their implications for novel drug development. J Pharmacol Exp Ther. 2003 Sep;306(3):821-7. https://doi.org/10.1124/jpet.102.041616

5. Ihl R, Bunevicius R, Frölich L, Winblad B, Schneider LS, Dubois B et al. World Federation of Societies of Biological Psychiatry guidelines for the pharmacological treatment of dementias in primary care. Int J Psychiatry Clin Pract. 2015 Mar;19(1):2-7. https://doi.org/10.3109/13651501.2014.961931

6. Wimo A, Jönsson L, Bond J, Prince M, Winblad B; Alzheimer Disease International. The worldwide economic impact of dementia 2010. Alzheimers Dement. 2013 Jan;9(1):1-11.e3. https://doi.org/10.1016/j.jalz.2012.11.006

7. Picon PD, Beltrame A, Banta D. National guidelines for highcost drugs in Brazil: achievements and constraints of an innovative national evidence-based public health policy. Int J Technol Assess Health Care. 2013 Apr;29(2):198-206. https://doi.org/10.1017/S0266462313000056

8. Costa RD, Osorio-de-Castro CG, Silva RM, Maia AA, Ramos MC, Caetano R. [The acquisition of medication to treat Alzheimer's disease in Brazil: an analysis of federal purchases, 2008-2013]. Cien Saúde Colet. 2015 Dec;20(12):3827-38. Portuguese. https://doi.org/10.1590/1413-812320152012.11542015

9. Almeida-Brasil CC, Costa JO, Aguiar VC, Moreira DP, Moraes EN, Acurcio FA et al. [Access to medicines for Alzheimer's disease provided by the Brazilian Unified National Health System in Minas Gerais State, Brazil]. Cad Saúde Pública. 2016 Aug;32(7):e00060615. Portuguese. https://doi.org/10.1590/0102-311X00060615

10. Moraes EN, Cintra MT. Belém D, Moraes FL. Evaluation of the Brazilian public Alzheimer's disease treatment program in 2008. Geriatr Gerontol Aging. 2013;7(1):14-9.

11. Pariente A, Helmer C, Merliere Y, Moore N, Fourrier-Réglat A, Dartigues JF. Prevalence of cholinesterase inhibitors in subjects with dementia in Europe. Pharmacoepidemiol Drug Saf. 2008 Jul;17(7):655-60. https://doi.org/10.1002/pds.1613

12. Hoffmann F, Bussche H, Glaeske G, Kaduszkiewicz $H$. Eight-year prescription trends of memantine and cholinesterase inhibitors among persons 65 years and older in Germany. Int Clin Psychopharmacol. 2010 Jan;25(1):29-36. https://doi.org/10.1097/YIC.0b013e3283339496

13. Franchi C, Lucca U, Tettamanti M, Riva E, Fortino I, Bortolotti A et al. Cholinesterase inhibitor use in Alzheimer's disease: the EPIFARMElderly Project. Pharmacoepidemiol Drug Saf. 2011 May;20(5):497-505. https://doi.org/10.1002/pds.2124

14. François M, Sicsic J, Elbaz A, Fleury NP. Trends in drug prescription rates for dementia: an observational population-based study in France, 2006-2014. Drugs Aging. 2017 Sep;34(9):711-21. https://doi.org/10.1007/s40266-017-0481-7
15. Dybicz SB, Keohane DJ, Erwin WG, McRae T, Shah SN. Patterns of cholinesterase-inhibitor use in the nursing home setting: a retrospective analysis. Am J Geriatr Pharmacother. 2006 Jun;4(2):154-60. https://doi.org/10.1016/j.amjopharm.2006.06.002

16. Di Santo SG, Prinelli F, Adorni F, Caltagirone C, Musicco M. A metaanalysis of the efficacy of donepezil, rivastigmine, galantamine, and memantine in relation to severity of Alzheimer's disease. J Alzheimers Dis. 2013;35(2):349-61. https://doi.org/10.3233/JAD-122140

17. Tan CC, Yu JT, Wang HF, Tan MS, Meng XF, Wang C et al. Efficacy and safety of donepezil, galantamine, rivastigmine, and memantine for the treatment of Alzheimer's disease: a systematic review and meta-analysis. J Alzheimers Dis. 2014;41(2):615-31. https://doi.org/10.3233/JAD-132690.

18. Picon PD, Camozzato AL, Lapporte EA, Picon RV, Moser Filho $\mathrm{H}$, Cerveira $\mathrm{MO}$ et al. Increasing rational use of cholinesterase inhibitors for Alzheimer's disease in Brazil: public health strategy combining guideline with peer-review of prescriptions. Int J Technol Assess Health Care. 2010 Apr;26(2):205-10. https://doi.org/10.1017/S0266462310000097

19. Forlenza OV. Ginkgo biloba and memory: myth or reality? Rev Psiquiatr Clin. 2003;30(6):218-220. https://doi.org/10.1590/S0101-60832003000600004

20. DeKosky ST, Williamson JD, Fitzpatrick AL, Kronmal RA, Ives DG, Saxton JA et al. Ginkgo biloba for prevention of dementia: a randomized controlled trial.JAMA. 2008 Nov;300(19):2253-62. https://doi.org/10.1001/jama.2008.683

21. Vellas B, Coley N, Ousset PJ, Berrut G, Dartigues JF, Dubois B et al. Long-term use of standardised Ginkgo biloba extract for the prevention of Alzheimer's disease (GuidAge): a randomised placebo-controlled trial. Lancet Neurol. 2012 Oct;11(10):851-9. https://doi.org/10.1016/S1474-4422(12)70206-5

22. Herrmann N, Black SE, Li A, Lanctôt KL. Discontinuing cholinesterase inhibitors: results of a survey of Canadian dementia experts. Int Psychogeriatr. 2011 May;23(4):539-45. https://doi.org/10.1017/S1041610210001535

23. Deardorff WJ, Feen E, Grossberg GT. The Use of Cholinesterase Inhibitors Across All Stages of Alzheimer's Disease. Drugs Aging. 2015 Jul;32(7):537-47. https://doi.org/10.1007/s40266-015-0273-x

24. Bradford A, Kunik ME, Schulz P, Williams SP, Singh H. Missed and delayed diagnosis of dementia in primary care: prevalence and contributing factors. Alzheimer Dis Assoc Disord. 2009 OctDec;23(4):306-14. https://doi.org/10.1097/WAD.0b013e3181a6bebc

25. Cummings JL. Use of cholinesterase inhibitors in clinical practice: evidence-based recommendations. Am J Geriatr Psychiatry. 2003 MarApr;11(2):131-145. https://doi.org/10.1097/00019442-200303000-00004

26. Gutierrez BA, Silva HS, Guimarães C, Campino AC. [Economic impact of Alzheimer's disease in Brazil: is it possible to improve care and minimize costs?]. Cien Saúde Colet. 2014 Nov;19(11):4479-86. Portuguese. https://doi.org/10.1590/1413-812320141911.03562013

27. Zilkens RR, Duke J, Horner B, Semmens JB, Bruce DG. Australian population trends and disparities in cholinesterase inhibitor use, 2003 to 2010. Alzheimers Dement. 2014 May;10(3):310-8. https://doi.org/10.1016/j.jalz.2013.04.001

28. Cooper C, Lodwick R, Walters K, Raine R, Manthorpe J, lliffe S et al. Observational cohort study: deprivation and access to anti-dementia drugs in the UK. Age Ageing. 2016 Jan;45(1):148-54. https://doi.org/10.1093/ageing/afv154

29. Scheffer M, coordinator. Demografia médica no Brasil 2015. São Paulo: Faculdade de Medidina da USP; 2015 [cited 2018 Mar 8]. Available from http://www.usp.br/agen/wp-content/uploads/ DemografiaMedica30nov2015.pdf 